\title{
The management of hyperkalaemia in the emergency department
}

\author{
Peter Ahee, Alexander V Crowe
}

\begin{abstract}
Life threatening hyperkalaemia $(>7.0$ mmol/1 ) is commonly associated with acute renal failure. Moderate hyperkalaemia ( 6.1-6.9 mmol/1) is also common and well tolerated in patients with chronic renal failure. Renal failure is the most common cause of hyperkalaemia although other causes to consider include drugs (potassium sparing diuretics, angiotensin converting enzyme inhibitors), hyperglycaemia, rhabdomyolysis and adrenal insufficiency. Hyperkalaemia affects the cardiac conducting tissue and can cause serious arrhythmias including ventricular fibrillation and asystolic arrest. Therefore it is important to treat hyperkalaemia promptly in the emergency department. This paper evaluates the therapeutic options available for treatment of hyperkalaemia.

(F Accid Emerg Med 2000;17:188-191)
\end{abstract}

Keywords: hyperkalaemia

Renal failure is the most common cause of hyperkalaemia seen in the emergency department. ${ }^{1}$ Clinically significant hyperkalaemia occurs in $5-10 \%$ of patients requiring regular haemodialysis. ${ }^{2}$ The medical management of hyperkalaemia in chronic renal failure $(\mathrm{CRF})$ is similar to that in acute renal failure (ARF) except that the rate of rise in ARF is usually more rapid and treatment must be more aggressive. ${ }^{3}$ Pseudohyperkalaemia (especially from extravascular haemolysis) is probably more common than true hyperkalaemia. Hence the plasma $\mathrm{K}$ should be rechecked before treatment is started unless there are electrocardiographic (ECG) changes.

Hyperkalaemia is classified as mild ( $\mathrm{K}$

Department of

Accident and

Emergency Medicine,

City Hospital,

Birmingham

P Ahee

Department of Nephrology, Royal Liverpool University Hospital

A V Crowe

Correspondence to: Dr Crowe, Senior Registrar in Nephrology, 6C Link, The Renal Unit, Royal Liverpool University Hospital, Prescot Street, Liverpool L7 8XP (e-mail: acrowe@)

liverpool.ac.uk)

Accepted for publication 8 December 1999 reduce the raised $\mathrm{K}$ levels.

Insulin and glucose is the current standard acute treatment. Recently, salbutamol has been advocated as equivalent to insulin and glucose with the advantage of nebulisation as an option. This review seeks to establish the efficacy, mechanism of action, onset and dura- tion of action and side effects of the currently used drugs in the management of moderate to severe hyperkalaemia in the emergency setting and to suggest a rationale for their effective use.

\section{Methods}

A literature search of Medline from 1993 to 1999 was performed linking the keywords "Hyperkalaemia", "Management", and "Treatment". Medline was also searched under the subject heading "HyperkalaemiaTreatment" from 1966 to 1999. The Cochrane library was searched under similar headings and there were no systematic reviews of the subject. References from articles recovered were searched for relevant studies.

The ideal design of a study of a treatment for hyperkalaemia is one that is randomised, blinded, and controlled against a placebo or standard therapy. Table 1 illustrates a summary of studies of the treatment of hyperkalaemia. Two studies ${ }^{915}$ were randomised (the method of randomisation was not stated). Two studies $^{27}$ were compared with placebo. The plasma $\mathrm{K}$ in these studies were relatively low as it would be unethical not to treat severely hyperkalaemic patients as insulin with glucose is an established treatment in an otherwise potentially fatal condition. One study ${ }^{1}$ was double blinded. Six studies ${ }^{2-15}$ had a crossover design to ensure uniformity in their comparisons.

Most studies examined patients with CRF; four studies ${ }^{411} 14$ included patients with ARF. Except for the studies that included paediatric patients only, ${ }^{414}$ the average age of the patients was more than 50 years. All studies excluded patients taking $\beta$ blockers and most excluded patients taking digoxin. In seven trials 2679101215 the $\mathrm{K}$ was only mildly increased $(\mathrm{K}<6.0 \mathrm{mmol} / \mathrm{l})$. In four studies 2101215 between $10 \%$ and $20 \%$ of patients did not complete the treatment, mostly because of going on to dialysis. Two studies ${ }^{6}{ }^{9}$ excluded non-responders (defined as patients who had a maximal reduction in $\mathrm{K}^{+}$of $<0.5 \mathrm{mmol} / 1$ after treatment) from their analysis.

\section{Initial management}

Treatment options include calcium (Ca) gluconate, insulin with glucose, salbutamol, sodium bicarbonate $\left(\mathrm{NaHCO}_{3}\right)$ and sodium (Na) polystyrene sulphonate.

\section{CALCIUM GLUCONATE}

There were no clinical studies looking solely at calcium in the management of hyperkalaemia. Ca gluconate antagonises cardiac membrane excitability and does not affect the plasma 
Table 1 Comparison of methodology of clinical studies of drug treatments

\begin{tabular}{|c|c|c|c|c|c|}
\hline Reference & $\underset{\text { size }}{\text { Sample }}$ & Inclusion criteria & Exclusion criteria & $\begin{array}{l}\text { Mean } \\
\text { initial K } \\
\text { (mmol/l) }\end{array}$ & $\begin{array}{l}\text { Crossover } \\
\text { design }\end{array}$ \\
\hline 2 & 10 & $\mathrm{CRF}$ & & 5.81 & yes \\
\hline 3 & 8 & $\mathrm{CRF}$ & ACE inhibitors & 6.3 & yes \\
\hline 4 & 13 & Child $<17 \mathrm{y} ; \mathrm{ARF}$ and $\mathrm{CRF}$ & & 6.7 & no \\
\hline 5 & 44 & $\mathrm{ARF}$ and $\mathrm{CRF}$ & IHD, DM & 7.0 & no \\
\hline 6 & 15 & CRF & & 5.53 & yes \\
\hline 7 & 5 & $\mathrm{CRF}$ & DM, IHD & 4.29 & yes \\
\hline 8 & 17 & CRF $(82 \%), \operatorname{ARF}(18 \%)$ & & 7.02 & no \\
\hline 9 & 34 & $\mathrm{CRF}$ & & 5.8 & no \\
\hline 10 & 12 & $\mathrm{CRF}$ & $\mathrm{DM}$ & 5.56 & yes \\
\hline 11 & 44 & CRF $(50 \%), \operatorname{ARF}(50 \%)$ & $\mathrm{DM}, \mathrm{IHD}$ & 7.0 & no \\
\hline 12 & 10 & $\mathrm{CRF}$ & ACE inhibitors & 5.62 & yes \\
\hline 13 & 10 & CRF; Able to cooperate & $\mathrm{DM}$ & 6.5 & no \\
\hline 14 & 15 & Children CRF (27\%), ARF (73\%) & Arrhythmias & 6.6 & no \\
\hline 15 & 11 & CRF & $\begin{array}{l}\text { Hypertension, IHD, DM } \beta \text { agonist, } \\
\text { steroids, xanthine derivatives }\end{array}$ & 5.9 & yes \\
\hline 16 & 9 & CRF & $\begin{array}{l}\mathrm{DM}, \beta \text { blockers, digoxin, } \mathrm{ACE} \\
\text { inhibitors }\end{array}$ & 5.99 & yes \\
\hline 17 & 45 & $\mathrm{CRF}$ & DM, asthma, IHD & $>6.0$ & no \\
\hline 18 & 9 & $\mathrm{CRF}$ & $\mathrm{DM}$ & 6.33 & no \\
\hline
\end{tabular}

$\mathrm{IHD}=$ ischaemic heart disease, $\mathrm{DM}=$ diabetes mellitus, $\mathrm{ACE}=$ angiotensin converting enzyme.

K. ${ }^{19}$ It is generally accepted that calcium should be given when there are ECG changes associated with hyperkalaemia. ${ }^{720}$ The sensitivity of emergency physicians diagnosing moderate to severe hyperkalaemia $(\mathrm{K}>6.5)$ from the ECG is only $62 \% .^{18}$ The ECG changes ${ }^{121}$ include tall $\mathrm{T}$ waves $>5 \mathrm{~mm}$ ( $\mathrm{K} 6-7$ ), small broad $\mathrm{P}$ waves or absent $\mathrm{P}$ waves, wide $\mathrm{QRS}$ complex (K 7-8), sinusoidal QRST (K 8-9) and atrioventricular dissociation or ventricular tachycardia/fibrillation $(\mathrm{K}>9)$. Twenty $\mathrm{ml}$ $10 \% \mathrm{Ca}$ gluconate ${ }^{19}$ is given intravenously in adults $\left(0.5 \mathrm{ml} / \mathrm{kg}\right.$ in children $\left.{ }^{8}\right)$ over $5-10 \mathrm{~min}$ utes and may be repeated as necessary. Onset of action is immediate but its duration is only a few minutes. ${ }^{119}$ Hyperkalaemic patients taking digoxin should be given calcium as a slow infusion over 20 to 30 minutes. This avoids hypercalcaemia that may potentiate the myocardial toxicity of digitalis.

\section{INSULIN WITH GLUCOSE}

Insulin binds to specific membrane receptors and via an unknown second messenger, stimulates the sodium-potassium (Na-K) adenosine triphosphatase (ATP) pump resulting in intracellular uptake of $\mathrm{K} .{ }^{5}$ This effect is independent of its hypoglycaemic action. Uraemia attenuates the hypoglycaemic response to insulin but does not affect its hypokalaemic action. $^{22}{ }^{23}$ Insulin has been the traditional temporising treatment against which newer treatments are compared. It is indicated in every case of hyperkalaemia that needs emergency treatment. Ten units (in adults) soluble insulin is given with $40-60 \mathrm{~g}$ glucose intravenously as a bolus.
In children, a glucose load of $0.5 \mathrm{~g} / \mathrm{kg} / \mathrm{h}(2.5$ $\mathrm{ml} / \mathrm{kg} / \mathrm{h}$ ) should be given. This is because many of these patients increase their endogenous insulin production with the administration of a glucose load. If the blood glucose rises above $10 \mathrm{mml} / 1$, insulin should be added at 0.05 $\mathrm{u} / \mathrm{kg} / \mathrm{h}^{24}$

Seven studies 35710121718 used insulin with glucose (table 2).

These studies show that the onset of hypokalaemic action is within 15 minutes and lasts for at least 60 minutes. ${ }^{71}$ The reduction in $\mathrm{K}$ observed is $0.65-1.0 \mathrm{mmol} / \mathrm{l}^{5}{ }^{10}$ Delayed (30-60 minutes post insulin) hypoglycaemia is common (up to $75 \%$ of patients ${ }^{10}$ ) if less than $30 \mathrm{~g}$ glucose is given.

SALBUTAMOL

Salbutamol binds to $\beta_{2}$ receptors in liver and muscle cells stimulating adenylate cyclase that converts ATP to 3'5'cyclic adenosine monophosphate. This stimulates the Na-K ATP pump resulting in intracellular $\mathrm{K}$ uptake. ${ }^{4}$ The response in patients on $\beta$ blockers and digoxin is attenuated. One author ${ }^{22}$ has expressed reservation that there may be a hyperkalaemic response in the first three minutes of its administration that could be potentially deleterious. This fear was based on a baboon study ${ }^{23}$ that used much higher doses intravenously $(100 \mu \mathrm{g} / \mathrm{kg})$ than have been used therapeutically in humans. Salbutamol $0.5 \mathrm{mg}(4 \mu \mathrm{g} / \mathrm{kg}$ in children) is given intravenously or $10 \mathrm{mg}$ of nebulised (Neb) salbutamol (in children: 2.5 $\mathrm{mg}$ if $<25 \mathrm{~kg}$ or $5 \mathrm{mg}$ if $>25 \mathrm{~kg}$ ).

Thirteen studies ${ }^{2-11}$ 13-16 $^{16}$ used salbutamol (table 3).

Table 2 Comparison of clinical studies of insulin with glucose

\begin{tabular}{lllllllll}
\hline & $\begin{array}{l}\text { Sample } \\
\text { Reference }\end{array}$ & $\begin{array}{l}\text { Dose of } \\
\text { soluble } \\
\text { insulin }\end{array}$ & $\begin{array}{l}\text { Dose } \\
\text { glucose }\end{array}$ & $\begin{array}{l}\text { Mean initial } \\
\text { K(mmolll) }\end{array}$ & $\begin{array}{l}\text { Peak } \\
\text { reduction in } \\
\text { K(mmoll) }\end{array}$ & $\begin{array}{l}\text { Time of } \\
\text { maximal } \\
\text { action (min) }\end{array}$ & $\begin{array}{l}\text { Duration of } \\
\text { effect (min) }\end{array}$ & Hypoglycaemia (\%) \\
\hline 3 & 8 & $5^{\star}$ & $40 \mathrm{~g}$ & 6.3 & 0.7 & 60 & $>60$ & 0 \\
5 & 10 & $10 \mathrm{U}$ & $40 \mathrm{~g}$ & 6.7 & 1.0 & 60 & $>360$ & 20 \\
7 & 5 & $5^{\star}$ & $60 \mathrm{~g}$ & 4.28 & 0.85 & 60 & $>60$ & 0 \\
10 & 12 & $10 \mathrm{U}$ & $25 \mathrm{~g}$ & 5.48 & 0.65 & 45 & $>60$ & 75 \\
12 & 10 & $5^{\star}$ & $5 \dagger$ & 5.62 & 0.92 & 60 & $>60$ & 50 \\
17 & 20 & $10 \mathrm{U}$ & $30 \mathrm{~g}$ & $>6.0$ & 0.98 & 180 & $>360$ & 0 \\
18 & 9 & $10 \mathrm{U}$ & $25 \mathrm{~g}$ & 6.33 & 0.76 & 60 & $>60$ & 11 \\
\hline
\end{tabular}

$\star=\mathrm{mU} / \mathrm{kg} / \mathrm{min}, \dagger=\mathrm{mg} / \mathrm{kg} / \mathrm{min}$. 
Table 3 Comparison of clinical studies of salbutamol

\begin{tabular}{|c|c|c|c|c|c|c|c|}
\hline Route & Reference & $\begin{array}{l}\text { Sample } \\
\text { size }\end{array}$ & Dose & $\begin{array}{l}\text { Mean } \\
\text { initial K } \\
(\text { mmol/l) }\end{array}$ & $\begin{array}{l}\text { Peak } \\
\text { reduction in } \\
K(\text { mmol/ll) }\end{array}$ & $\begin{array}{l}\text { Time of } \\
\text { maximal } \\
\text { action } \\
\text { (min) }\end{array}$ & $\begin{array}{l}\text { Duration } \\
\text { of effect } \\
\text { (min) }\end{array}$ \\
\hline IV & 4 & 13 & $4 \mu \mathrm{g} / \mathrm{kg}$ & 6.7 & 1.48 & 40 & $>120$ \\
\hline IV & 5 & 24 & $0.5 \mathrm{mg}$ & 7.0 & 1.4 & 30 & $>360$ \\
\hline IV & 6 & 15 & $0.5 \mathrm{mg}$ & 5.53 & $0.92^{\star}$ & 30 & $>180$ \\
\hline IV & 8 & 17 & $4 \mu \mathrm{g} / \mathrm{kg}$ & 7.02 & 1.32 & 40 & $>120$ \\
\hline IV & 9 & 17 & $0.5 \mathrm{mg}$ & 5.7 & $0.95^{\star}$ & 30 & $>180$ \\
\hline IV & 11 & 24 & $0.5 \mathrm{mg}$ & 7.0 & 1.4 & 30 & $>360$ \\
\hline IV & 14 & 15 & $5 \mu \mathrm{g} / \mathrm{kg}$ & 6.6 & 1.69 & 120 & $>180$ \\
\hline IV & 15 & 11 & $4 \mu \mathrm{g} / \mathrm{kg}$ & 5.6 & 0.87 & 30 & 120 \\
\hline $\mathrm{Neb}$ & 2 & 10 & $10 \mathrm{mg}$ & 5.93 & 0.62 & 90 & $>120$ \\
\hline Neb & 2 & 10 & $20 \mathrm{mg}$ & 5.81 & 0.98 & 90 & $>120$ \\
\hline $\mathrm{Neb}$ & 6 & 15 & $10 \mathrm{mg}$ & 5.66 & $0.85^{\star}$ & 90 & $>180$ \\
\hline $\mathrm{Neb}$ & 7 & 5 & $10 \mathrm{mg}$ & 4.29 & 0.53 & 60 & $>60$ \\
\hline $\mathrm{Neb}$ & 9 & 17 & $10 \mathrm{mg}$ & 5.8 & $0.88^{\star}$ & 90 & $>180$ \\
\hline $\mathrm{Neb}$ & 10 & 12 & $20 \mathrm{mg}$ & 5.56 & 0.66 & 60 & $>60$ \\
\hline $\mathrm{Neb}$ & 13 & 10 & $15 \mathrm{mg}$ & 6.5 & 0.9 & 30 & $>360$ \\
\hline $\mathrm{Neb}$ & 15 & 11 & $2.5 / 5 \mathrm{mg} \dagger$ & 5.9 & 0.61 & 30 & $>300$ \\
\hline $\mathrm{Neb}$ & 16 & 9 & $15 \mathrm{mg}$ & 5.99 & 0.57 & 60 & $>60$ \\
\hline
\end{tabular}

${ }^{\star}$ Excluded non-responders from analysis, $\dagger 2.5 \mathrm{mg}$ if $<25 \mathrm{~kg} ; 5 \mathrm{mg}$ if $>25 \mathrm{~kg}$. IV $=$ intravenous, $\mathrm{Neb}=$ nebulised

Salbutamol produced a reduction in $\mathrm{K}$ of 0.87-1.4 $\mathrm{mmol} / 1$ after intravenous administration $^{5}{ }^{15}$ and $0.53-0.98 \mathrm{mmol} / 1$ after nebulisation. ${ }^{2} 7$ Most studies used $10 \mathrm{mg}$ nebulised salbutamol but $20 \mathrm{mg}$ has been shown to be more effective at 120 minutes than $10 \mathrm{mg}^{2}$ No difference was found when insulin with glucose was compared with intravenous salbutamol ${ }^{5}$ or nebulised salbutamol. ${ }^{10}$ Onset of action was within 30 minutes. There was no difference in maximum effect when intravenous salbutamol was compared with nebulised salbutamol. ${ }^{6}{ }^{15}$ However, the maximum effect was in 30 minutes for intravenous administration compared with 90 minutes for nebulisation. Tremor and tachycardia were more pronounced after intravenous treatment. Caution has been advised for use in patients with ischaemic heart disease. Some authors ${ }^{6}{ }^{9}$ suggest nebulised treatment only in these patients.

Some $12-40 \%$ patients ${ }^{810}$ were unresponsive to salbutamol and it should always be used in conjunction with insulin. The cause of this unresponsiveness is unknown. ${ }^{22}$

Two studies ${ }^{510}$ combined salbutamol and insulin with glucose (table 4). The combination of salbutamol and insulin was more effective than insulin alone in these studies. The hypoglycaemia associated with insulin was attenuated.

SODIUM BICARBONATE

$\mathrm{NaHCO}_{3}$ has been recommended in textbooks for many years. It has no significant action on plasma $K$ in the first 60 minutes after administration. ${ }^{371216}$ It may be indicated in severe metabolic acidosis $(\mathrm{pH}<7.2),{ }^{19}{ }^{20}$ which may be an associated feature in ARF. Potential risks in giving $\mathrm{NaHCO}_{3}$ include hypernatrae-
Table 5 Comparison of clinical studies of $\mathrm{NaHCO}_{3}$

\begin{tabular}{lllll}
\hline Reference & $\begin{array}{l}\text { Sample } \\
\text { size }\end{array}$ & $\begin{array}{l}\text { Dose } \\
\text { NaHCO} \\
(\text { mmol) }\end{array}$ & $\begin{array}{l}\text { Concentration } \\
(\%)\end{array}$ & $\begin{array}{l}\text { Mean initial } \\
\text { K (mmol/l) }\end{array}$ \\
\hline 3 & 8 & 120 & 8.4 & 6.4 \\
7 & 5 & 90 & 1.4 & 4.23 \\
12 & 10 & 240 & 8.4 & 5.66 \\
& 10 & 120 & 1.4 & 5.83 \\
16 & 9 & $2 / \mathrm{kg}$ & 8.4 & 5.98 \\
\hline
\end{tabular}

mia, volume overload and tetany in patients with CRF and coexistent hypocalcaemia.

Four studies ${ }^{371216}$ examined the efficacy of $\mathrm{NaHCO}_{3}$ (table 5) and all failed to show any reduction in $\mathrm{K}$ within 60 minutes.

These trials did not include patients with severe hyperkalaemia or severe metabolic acidosis. Allon and Shanklin ${ }^{7}$ reported that $\mathrm{NaHCO}_{3}$ had no additive effect on the action of insulin or salbutamol while $\mathrm{Kim}^{3}{ }^{16}$ reported that $\mathrm{NaHCO}_{3}$ increased the effect of insulin and salbutamol. The patients in Kim's studies had a higher initial plasma $\mathrm{K}$.

\section{SODIUM POLYSTYRENE SULPHONATE}

(KAYEXALATE)

There were no clinical studies looking specifically at the efficacy of $\mathrm{Na}$ polystyrene sulphonate in the management of hyperkalaemia. This resin binds $\mathrm{K}$ in the intestinal lumen, especially large bowel and ileum. ${ }^{19}$ It may be indicated if haemodialysis is delayed $(>2-3$ hours). ${ }^{19}$ Fifty grams $\mathrm{Na}$ polystyrene sulphonate in $100-200 \mathrm{ml} 30 \%$ sorbitol or $10 \%$ glucose at $37^{\circ} \mathrm{C}$ is given rectally and left for at least 60 minutes. Sorbitol is added as it increases faecal $\mathrm{K}$ excretion. The onset of action is slow, approximately one to two hours. One gram resin exchanges $1 \mathrm{mEq} \mathrm{Na}$ for $1 \mathrm{mEq}$ $\mathrm{K} .{ }^{1}$ Rarely, ulceration of the bowel mucosa can occur, especially in constipated patients, and is probably attributable to to the action of sorbitol. ${ }^{25}$ Concurrent use of a laxative helps prevent faecal impaction.

\section{HAEMODIALYSIS}

This is the definitive and most effective hypokalaemic measure. ${ }^{122}$ It is indicated in severe hyperkalaemia. Mild to moderate hyperkalaemia in CRF may be managed without haemodialysis as an emergency depending on the cause. It has been reported to be of benefit in patients who have had a hyperkalaemic cardiac arrest when drug measures have failed. ${ }^{26}$ During haemodialysis, plasma $\mathrm{K}$ falls rapidly in the first hour and very little thereafter. ${ }^{12}$ If a potassium free dialysate is used, serum potassium may decrease as much as 1.2 to 1.5 $\mathrm{mEq} / \mathrm{h}{ }^{27}$ Potassium concentrations show a rebound after dialysis has finished and this rebound may require several hours to reach a

Table 4 Comparison of studies of combined salbutamol and insulin with glucose

\begin{tabular}{|c|c|c|c|c|c|c|c|c|c|}
\hline Reference & Size & $\begin{array}{l}\text { Dose } \\
\text { soluble } \\
\text { insulin }\end{array}$ & $\begin{array}{l}\text { Dose } \\
\text { Glu }\end{array}$ & $\begin{array}{l}\text { Route } \\
\text { Salb }\end{array}$ & Dose Salb & $\begin{array}{l}\text { Mean initial K } \\
(\mathrm{mmol} / \mathrm{l})\end{array}$ & $\begin{array}{l}\text { Peak reduction } \\
\text { in } K(\text { mmol/l) }\end{array}$ & $\begin{array}{l}\text { Time of } \\
\text { maximal action } \\
\text { (min) }\end{array}$ & $\begin{array}{l}\text { Duration of } \\
\text { effect (min) }\end{array}$ \\
\hline 5 & 10 & $10 \mathrm{U}$ & $40 \mathrm{~g}$ & IV & $0.5 \mathrm{mg}$ & 7.1 & 1.5 & 60 & $>360$ \\
\hline 10 & 12 & $10 \mathrm{U}$ & $25 \mathrm{~g}$ & $\mathrm{Neb}$ & $20 \mathrm{mg}$ & 5.89 & 1.21 & 60 & $>60$ \\
\hline
\end{tabular}

Glu $=$ glucose, Salb = salbutamol. 
plateau. ${ }^{28}$ If the potassium is lowered with other agents such as salbutamol, this may reduce potassium removal during subsequent dialysis treatment, even though the achieved potassium concentration is lower. ${ }^{29}$

\section{Conclusions}

The emergency management of hyperkalaemia should be tailored to the individual patient. It involves (1) determining the cause and (2) instituting temporising measures to stabilise the myocardium and lower the plasma $\mathrm{K}$ by redistribution to the intracellular compartment while (3) arranging haemodialysis if necessary. Urgency of treatment is dependent on rate of rise of $\mathrm{K}$ in addition to the plasma concentration.

Using common sense interpretation of the available studies, moderate to severe hyperkalaemia in the emergency department should be treated (after confirmation) with (1) Ca gluconate if there are any ECG changes followed by (2) insulin with glucose and (3) intravenous salbutamol (nebulised if there is evidence of ischaemic heart disease). $\mathrm{NaHCO}_{3}$ does not lower the $\mathrm{K}$ in the first 60 minutes but is given if there is severe metabolic acidosis $(\mathrm{pH}$ $<7.20$ ). Sodium polystyrene sulphonate can be given if there is an anticipated delay in haemodialysis, which is the definitive treatment in these patients.

Contributors

Ahee initiated, edited and coordinated the writing of the paper. Crowe provided core ideas from a nephrology perspective and edited the paper. Both authors are acting as guarantors. Funding: none.

Conflicts of interest: none.

1 Mandal AK. Hypokalemia and hyperkalemia. Med Clin North Am 1997;81:611-39.

2 Allon M, Dunlay R, Copkney C. Nebulised albuterol for acute hyperkalemia in patients on hemodialysis. Ann Intern acute hyperkalemia in
Med $1989 ; 110: 426-9$

$3 \mathrm{Kim}$ HJ. Combined effect of bicarbonate and insulin with glucose in acute therapy of hyperkalemia in end-stage renal disease patients. Nephron 1996;72:476-82.

4 Murdoch IA, Dos Anjos R, Haycock GB. Treatment of hyperkalemia with intravenous salbutamol. Arch Dis Child 1991;66:527-8.

5 Lens XM, Montoliu J, Cases A, et al. Treatment of hyperkalemia in renal failure: Salbutamol v insulin. Nephrol Dial Transplant 1989;4:228-32.

6 Liou HH, Chiang SS, Wu SC, et al. Hypokalemic effects of intravenous infusion or nebulization of salbutamol in patients with chronic renal failure: comparative study. $A m \mathcal{F}$ Kidney Dis 1994;23:266-71.

7 Allon M, Shanklin N. Effect of bicarbonate administration on plasma potassium in dialysis patients: interactions with insulin and albuterol. Am f Kidney Dis 1996;28:508-14.
8 Noyan A, Anarat A, Pirti M, et al. Treatment of hyperkalemia in children with intravenous salbutamol. Acta Paediatr fpn 1995;37:355-7.

9 Liou HH, Chiang SS, Wu SC, et al. Intravenous infusion or nebulization of salbutamol for treatment of hyperkalemia in patients with chronic renal failure. Chung Hua I Hsueh Tsa Chih Taipei 1994;53:276-81.

10 Allon M, Copkney C. Albuterol and insulin for treatment of hyperkalemia in hemodialysis patients. Kidney Int 1990;38: 869-72.

11 Montoliu J, Lens XM, Revert L. Potassium-lowering effect of albuterol for hyperkalemia in renal failure. Arch Intern Med 1987;147:713-17.

12 Blumberg A, Weidmann P, Shaw S, et al. Effect of various therapeutic approaches on plasma potassium and major regulating factors in terminal renal failure. $\mathrm{Am} \mathrm{f} \mathrm{Med}$ 1988;85:507-12.

13 Montoliu J, Almirall J, Ponz E, et al. Treatment of hyperkalemia in renal failure with salbutamol inhalation. F Intern Med 1990;228:35-7.

14 Kemper MJ, Harps E, Hellwege $\mathrm{HH}$, et al. Effective treatment of acute hyperkalaemia in childhood by shortterm infusion of salbutamol. Eur F Pediatr 1996;155:495-7.

15 McClure RJ, Prasad VK, Brocklebank JT. Treatment of hyperkalaemia using intravenous and nebulised salbutamol. Arch Dis Child 1994;70:126-8.

$16 \mathrm{Kim}$ HJ. Acute therapy for hyperkalemia with the combined regimen of bicarbonate and beta(2)-adrenergic agonist (salbutamol) in chronic renal failure patients. $\mathcal{F}$ Korean Med Sci 1997;12:111-16.

17 Duranay M, Ates K, Erturk S, et al. Comparison of aminophylline and insulin infusions in treatment of hyperkalemia in patients with end-stage renal disease. Nephron 1996;73: in patien.

18 Ljutic D, Rumboldt Z. Should glucose be administered before, with, or after insulin, in the management of hyperkalemia? Ren Fail 1993;15:73-6.

19 Allon M. Treatment and prevention of hyperkalemia in endstage renal disease. Kidney Int 1993;43:1197-209.

20 Salem MM, Rosa RM, Batlle DC. Extrarenal potassium tolerance in chronic renal failure: implications for the treatment of acute hyperkalemia. Am $\mathcal{F}$ Kidney Dis 1991;18:421-40.

21 Wrenn KD, Slovis CM, Slovis BS. The ability of the physician to predict hyperkalemia from the ECG. Ann Emerg Med 1991;20:1229-32.

22 Semmekrot BA, Monnens LA. A warning for the treatment of hyperkalaemia with salbutamol. Eur f Pediatr 1997;156: 420.

23 Du-Plooy WJ, Hay L, Kahler CP, et al. The dose-related hyper-and-hypokalaemic effects of salbutamol and its arrhythmogenic potential. Br f Pharmacol 1994;111:73-6.

24 Advanced Life Support Group. Paediatric life support: the practical approach. 2nd ed. London: BMJ Publishing Group, 1997:254

25 Roy-Chaudhury P, Meisels IS, Freedman S, et al. Combined gastric and ileocecal toxicity (serpiginous ulcers) after oral kayexalate in sorbital therapy. Am f Kidney Dis 1997;30: $120-2$.

26 Lin JL, Lim PS, Leu ML, et al. Outcomes of severe hyperkalemia in cardiopulmonary resuscitation with concomitant hemodialysis. Intensive Care Med 1994;20:287-90.

27 Blumberg A, Weidman P, Shaw S, et al. Effect of various therapeutic approaches on plasma potassium and major regulating factors in terminal renal failure. Am f Med 1988; 85:507-12.

28 Feig PU, Shook A, Sterns RH. Effect of potassium removal during haemodialysis on the plasma potassium concentration. Nephron 1981;27:25-30

29 Allon M, Shanklin N. Effect of albuterol treatment on subsequent dialytic potassium removal. Am f Kidney Dis 1995; 26:607-13. 